\title{
人カで走行する倒立振子型安定化車両の操舵性能*
}

\author{
中川 智皓 ${ }^{* 1}$, 中野 公彦 ${ }^{* 2}$, 須田 義大 ${ }^{* 3}$, 平山 遊喜 ${ }^{* 4}$
}

\section{Steering Performance of a Human-Powered Dynamically Stabilized Vehicle}

\author{
Chihiro NAKAGAWA*1 ${ }^{*}$, Kimihiko NAKANO, Yoshihiro SUDA and Yuki HIRAYAMA \\ ${ }^{* 1}$ Osaka Prefecture University, Graduate School of Engineering \\ 1-1 Gakuen-cho, Naka-ku, Sakai, Osaka, 599-8531 Japan
}

In this paper, the steering performance of a human-powered dynamically stabilized vehicle is investigated as one of the forms of Personal Mobility Vehicles (PMV). The produced prototype vehicle has the reaction force actuator and it reacts according to the handle steering input. The turning is realized by the differential of the rotation of the right and left wheels. The steering system is designed by the steering dynamics of the bicycle. In the experiment, the errors from the target trajectory were measured and the maneuverability was evaluated by the subjects. It was shown that setting the driving torque of the wheels using the gain proportional to the handle steering angle and its rate had high performance.

Key Words : Transport, Motion Control, Simulation, Personal Mobility Vehicle, Two-Wheel Vehicle, Inverted Pendulum, Pedaling

\section{1. 緒 論}

近年, 地球環境保全, 高齢社会, 移動権確保への対応から，従来の交通システムではカバーできない新たな交 通モードを実現するモビリティが要請されてきている，著者らは，新しい個人の移動手段となるパーソナルモビ リティ・ビークル（Personal Mobility Vehicle, PMV）について, 自動車未満, 歩行以上の移動手段となるコンセプ トの車両を提案してきた。提案した形態の一つであるペダル式倒立振子型安定化車両は, 人力と電力を組み合わ

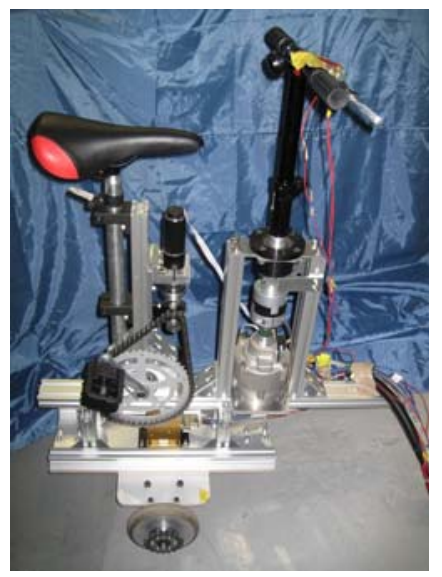

Fig.1 Human-powered dynamically stabilized vehicle with the steering system

\footnotetext{
* 原稿受付 2010 年 11 月 11 日

*1 正員, 大阪府立大学 工学研究科（二599-8531 大阪府堺市中区学園町 1-1）

*2 正員, 東京大学 情報学環・学際情報学府（广153-8505 東京都目黒区駒場 4-6-1）

*3 正員，フェロー，東京大学 生産技術研究所（干153-8505 東京都目黒区駒場 4-6-1）

*4 東京大学大学院 情報学環 ・ 学際情報学府（广153-8505 東京都目黒区駒場 4-6-1）

E-mail: chihiro@me.osakafu-u.ac.jp
} 
せた新しい走行方式の PMVである(1).

これまで，倒立振子の制御理論を用いた搬送車両，ロボット，乗り物の研究は多くなされている．倒立振子型 ロボットの安定化制御ロジックの構築や目標軌道追従の手法が紹介されている ${ }^{(2,3)}$. 複数の倒立振子型ロボットが サッカーを行うシステムの研究例もある. 人間が乗車することを目的とした倒立振子型車両の製作や実験も複数 行われている ${ }^{(4,5)}$. 特に，人間一車両間の協調に関寸る研究は，近年学術的にも注目されてきており，人間の外乱 または意図を考慮した倒立振子型車両の制御も見受けられる(6). 倒立振子型車両のロールに関する安定性につい ては，ロール方向に姿勢変更可能なステップを用いた検討例がある(7). しかしながら，これら従来の二輪倒立振 子型安定化車両は, 基本的にモータの駆動力のみによって走行するものである. 本研究での提案車両は, 車輪が 人力でも駆動するようペダルによる伝達機構を付加し，人力と協調した制御を行う. 安定化制御を行いつつ, 人 がペダルをこぐことにより発電機で電力を発生させ，人の力と電気の力を効率よく組み合わせて走行する新しい 技術と言える。これまで, ペダル式倒立振子型安定化車両の安定性を, シミュレーションと試作機を用いた実験 から検討し，人間が車両に乗車し，倒立姿勢を保持しながら，前進できることを確認している ${ }^{(8)}$. 本論文では, ペダル式倒立振子型安定化車両の操舵性能について述べる. 操舵可能なペダル式倒立振子型安定化車両の試作車 を図 1 に示寸.

\section{2. 操舵制御システム}

\section{$2 \cdot 1$ 操舵制御システム}

実験装置全体のシステムを図 2 に示寸，車体のピッチ，車輪部の駆動モータの回転，ペダル部の回転の情報を 取得し, DSPからサーボアンプヘ電流指令を送り, 車輪が駆動するシステムに, 操舵システムを付加した. 操舵 システムでは, 操舵角, 操舵トルク, モータ電流の情報を取得し, DSP から ECU ヘトルク指令を送り, 操舵反 力が出力される. また， ハンドル操舵情報に応じて，左右車輪それぞれに駆動指令が送られる．ここでは，操舵 反カアクチュエータが設置された試作車を用いて実験を行う。試作車の概観を図 3 に示寸.

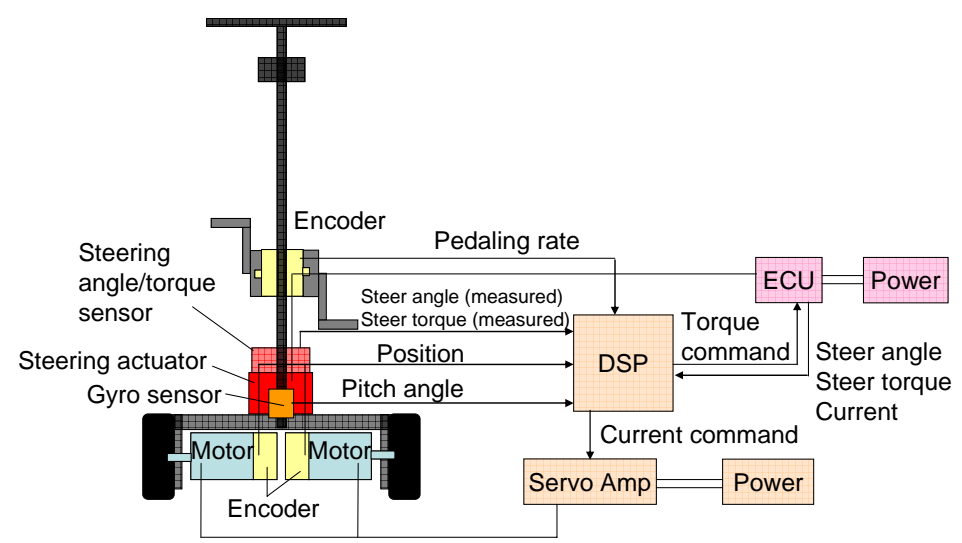

Fig.2 System of the vehicle 


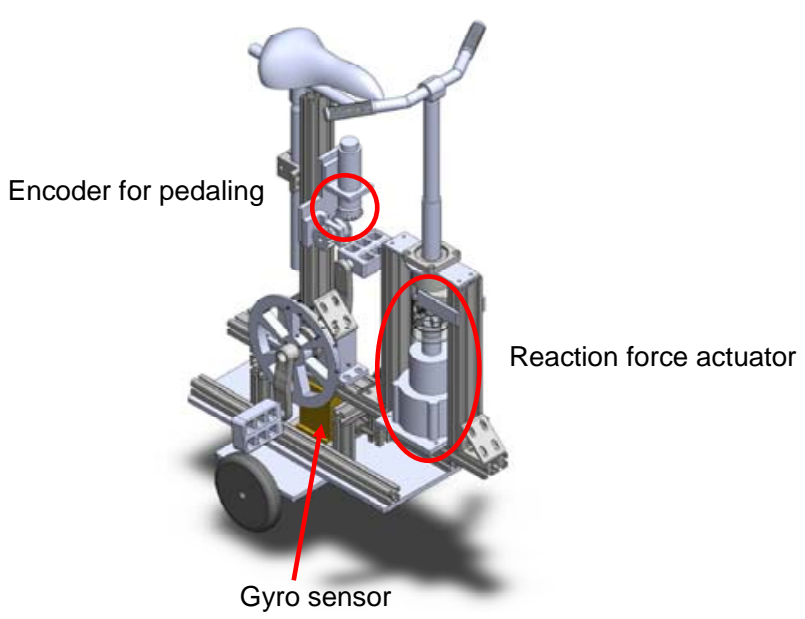

Fig.3 Steering system

\section{$2 \cdot 2$ 操舵システム設計}

ペダル式倒立振子型安定化車両の操舵システム設計には，複数の思想が考えられる．例えば，操舵システム設 計の目標として，人間の負担を軽減するもの，エネルギ消費を抑制するもの，センサやアクチュエータなどの部 品点数を削減し, 簡略化するものなどが挙げられる. 著者らは, 運動力学, 安定性の観点から, 低速では倒立振 子型車両, 高速では自転車の形態となる PMV 形態を提案している ${ }^{(9)}$. よって, ここでは, 自転車モードとの互換 性を考慮し, できるだけ自転車と違和感のない操舵系を実現する設計思想に基づき, 操舵システムを構築する.

まず, 自転車における操舵反力トルクを検討する. ここでは, 直進走行する自転車の線形モデルを用いる ${ }^{(10)}$. 自転車モデルの基本的な運動方程式を利用して, 提案したペダル式倒立振子型安定化車両の独自の運動を定める. 図 4 に自転車モデルの前輪系を示す．自転車のフロントステア部まわりに生じるトルク $T_{\phi}$ は,

$$
T_{\phi b s}=\operatorname{Mgat}\left(c_{c} \beta_{f}+\left(1-c_{t}\right) \gamma_{f}\right) \sin \alpha
$$

と表される，ここで， $M$ は全重量， $g$ は重力加速度， $a$ は全重量のうち前輪が負担する割合， $t$ はトレール， $\alpha$ は ヘッド角， $c_{c}$ はコーナリング係数， $c_{t}$ はキャンバ係数である. $\beta_{r}, \gamma_{r}$ はそれぞれ前輪の横すべり角，キャンバ角で あり，フロントステア角が 0 のときの接地点での横すべり速度を $v_{c f}$ とすると，

$$
\beta_{f}=\left(v_{c f}-(r \cos \alpha-f)\right) \dot{\phi}_{s} / V-\phi_{s} \sin \alpha
$$

$$
\gamma_{f}=\theta+\phi_{s} \cos \alpha
$$

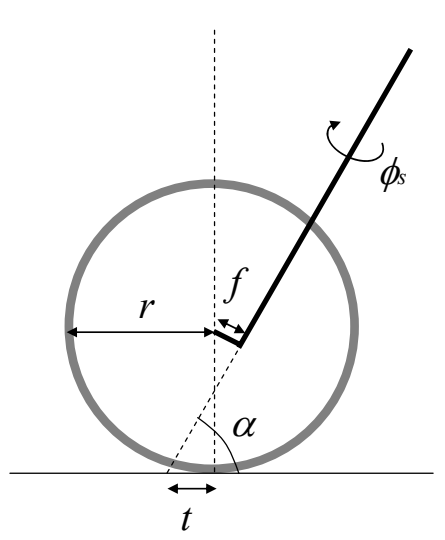

Fig.4 Front steer system of the bicycle 
と表される， $r$ は車輪半径， $f$ はオフセット， $V$ は走行速度である. 自転車本体の運動については前後輪とも横す ベりは小さいと仮定し, フロントステアによる項のみを残して, $v_{c f}=0$ とする. ペダル式倒立振子型安定化車両の 実験では，ロール角 $\theta$ は 0 とし，式(2),(3)を式(1)に代入すると，操舵反力トルクは，

$$
T_{\varphi_{b s}}=\operatorname{Mgat}\left(c_{c}\left(-(r \cos \alpha-f) \dot{\varphi}_{s} / V-\varphi \sin \alpha\right)+\left(1-c_{t}\right) \varphi_{s} \cos \alpha\right) \sin \alpha
$$

となる，フロントステア周りのトルクについて，自転車とペダル式倒立振子型安定化車両の関係式を導く．自転 車のフロントステア慣性モーメント $I_{b}$ とペダル式倒立振子型安定化車両のフロントステア慣性モーメント $I_{p}$ を用 いると，ペダル式倒立振子型安定化車両に与える操舵反力トルク $T_{\phi p s}$ は,

$$
T_{\phi p s}=\frac{I_{p}}{I_{b}} T_{\phi b s}
$$

と導出される. 式(4)を式(5)に代入し，整理すると，

$$
T_{\phi s}=K_{r} \phi_{s}+C_{r} \frac{1}{V} \dot{\phi}_{s}
$$

となる.ここで，

$$
\begin{gathered}
K_{r}=\frac{I_{p}}{I_{b}} \operatorname{Mgat}\left(\left(1-c_{t}\right) \cos \alpha-c_{c} \sin \alpha\right) \sin \alpha \\
C_{r}=\frac{I_{p}}{I_{b}} \operatorname{Mgatc}_{c}(f-r \cos \alpha) \sin \alpha
\end{gathered}
$$

である. 導出した式(6)より, 自転車のフロントステア軸周りの反カトルクを模擬したペダル式倒立振子型安定化 車両における操舵反力トルクは, 操舵角, 操舵角速度に比例し, 走行速度に反比例することが分かる.

次に，自転車の旋回についても同様に，自転車の線形モデルを用いて検討する. 自転車のヨー方向に関する慣 性モーメントを $I_{y b}$, 前後輪の横力を $F_{f}, F_{r}$ とすると,

$$
I_{y b} \ddot{\psi}=F_{f} l_{f}-F_{r} l_{r}
$$

と表される.ここで, 横すべりは小さいものとすると, タイヤから発生する横向きの力はタイヤ横すべり角に比 例すると見なせ，以下のように表される.

$$
\begin{aligned}
& F_{f}=-K_{f} \beta_{f}-C_{f} \gamma_{f} \\
& F_{r}=-K_{r} \beta_{r}-C_{r} \gamma_{r}
\end{aligned}
$$

比例定数 $K_{f}, K_{r}$ はコーナリングパワー $, C_{f}, C_{r}$ はキャンバスラスト係数である. ここでは, 前輪のみ操舵する一 般的な自転車を考える.ペダル式倒立振子型安定化車両の実験では，ロール角 $\theta$ は 0 とし，式(10),(11)を式(9)に代 入すると，旋回トルクは，

$$
I_{y b} \ddot{\psi}=\left(K_{f} \sin \alpha-C_{f} \cos \alpha\right) l_{f} \phi_{s}+K_{f}(r \cos \alpha-f) / V \dot{\phi}
$$


と導出できる.ペダル式倒立振子型安定化車両のヨー方向に関する慣性モーメント $\mathrm{I}_{\mathrm{yp}}$ を用いると, ペダル式倒立 振子型安定化車両に与える旋回トルク $T_{\phi}$ は,

$$
T_{\phi p t}=I_{y p} \ddot{\psi}=\frac{I_{y p}}{I_{y b}}\left(K_{f} \sin \alpha-C_{f} \cos \alpha\right) l_{f} \phi_{s}+\frac{I_{y p}}{I_{y b}} K_{f}(r \cos \alpha-f) / V \dot{\phi}_{s}
$$

となる. 本研究で取り扱うぺダル式倒立振子型安定化車両では, その場での旋回運動も可能とするシステムにす るため, 直進時の左右車輪の駆動卜ルク $\tau_{\mathrm{w}}$ に, 旋回指令に応じた車輪駆動トルクを左右車輪で逆向きに加えるこ ととする．左右車輪それぞれの車輪駆動トルク $\tau_{\text {tur_R }}, \tau_{\text {tur_L }}$ は次のように表される.

$$
\tau_{\text {turn } n_{-} R}=\tau_{w}-T_{\phi p s}, \quad \tau_{\text {turn } L} L=\tau_{w}+T_{\phi_{p s}}
$$

ペダル式倒立振子型安定化車両の左右の車輪駆動力の大きさを $F$, ペダル式倒立振子型安定化車両の重心から左 右各々の車輪位置までの水平距離を $l_{p}$ とすると,

$$
T_{\phi p}=2 F l_{p}=K_{p} \phi_{s}+C_{p} \dot{\phi}_{s}
$$

と表される.ただし，

$$
\begin{gathered}
K_{p}=\frac{I_{y p}}{I_{y b}}\left(K_{f} \sin \alpha-C_{f} \cos \alpha\right) l_{f} \\
C_{p}=\frac{I_{y p}}{I_{y b}} K_{f}(r \cos \alpha-f) / V
\end{gathered}
$$

である．整理すると，

$$
F=\frac{K_{p}}{2 l_{p}} \phi_{s}+\frac{C_{p}}{2 l_{p}} \dot{\phi}_{s}
$$

が得られ，ペダル式倒立振子型安定化車両の左右各々の車輪駆動トルクの大きさは，

$$
T_{\phi_{p t}}=F r=\frac{K_{p} r}{2 l_{p}} \phi_{s}+\frac{C_{p} r}{2 l_{p}} \dot{\phi}_{s}
$$

と表される. よって, 操舵角, 操舵角速度に対する旋回ゲインは,

$$
\begin{gathered}
K_{t}=\frac{K_{p} r}{2 l_{p}} \\
C_{p}=\frac{I_{y p}}{I_{y b}} K_{f}(r \cos \alpha-f) / V
\end{gathered}
$$

と導出される. ただし，倒立振子型安定化車両のその場での旋回を含む小回り旋回については，自転車モデルで は表現に限界があるため, 実験において旋回ゲインを調整する必要がある. 
以上より, 導出された式(6), (19) によって, 自転車の操舵力学を利用したペダル式倒立振子型安定化車両の独 自の運動が定められた。

\section{3. 操舵制御実験}

\section{$3 \cdot 1$ 実験条件}

操舵制御実験の条件を設定する，直進時の駆動指令は，ペダル回転速度に比例した目標ピッチ角を与える制御 指令とした．駆動制御実験において，被験者の評価が高いシステムであったためである(11)。操舵システムにお ける反カトルクゲイン $K_{r}, C_{r}$, 旋回ゲイン $K_{t,} C_{t}$ は, 走行速度 $1 \mathrm{~m} / \mathrm{s}$ の 6 インチ小径自転車の諸元を用いて導出し た．実験において，反力トルクゲインは，導出された值 $K_{r}=-0.1177, C_{r}=-0.00213$ を用いる. このときに操舵反力 系の減衰比は， 0.16 となる. 旋回ゲインについては，導出された值 $K_{t}=16.7, C_{t}=0.282$ を元に，複数通りのゲイン 設定を行い，操縦性を比較する．まず $C_{t}=0$ とし， $K_{t}=K_{t} ， 10^{-1} K_{t} ， 10^{-2} K_{t} ， 10^{-3} K_{t}$ のそれぞれに設定し，その 中で最も評価が高かったゲイン $K_{t}$ を用いて，ゲイン $C_{t}$ を調整する手順とした，ゲインの設計と条件，調整また 実験までのフロー図を図 5 に示す，以上の手順により，試験条件は表 1 に示す 6 つの条件とした.

走行試験で用いる試験コースを図 5 に示す。ペダル式倒立振子型安定化車両では，自転車では困難な小回り旋 回を実現することが特徵の一つであるため, 小さい旋回半径を持つ曲線と直線を組み合わせた目標コースを設定 した. 図 6 に示される丸印が出発点であり，矢印が到着点である.8 の字型の試験コースである.2つの×印間の 距離は $2 \mathrm{~m}$ である. 目標コースにおける曲線の旋回半径は, $0.5 \mathrm{~m}$ である.

操縦被験者は，20 代男性 5 名とし，実験前に操縦の練習を行った．実験では，目標コースに対して，操縦被験 者の意図通りに車両が走行可能であるかを評価する．操縦被験者は，表 1 に示したそれぞれの条件の下，2回ず つ操縦を行った。それぞれの条件に対し，操縦性を 5 段階で評価した。操縦の様子を図 7 に示す。実験用の試験 路では, 車両軌跡のデータ取得のため, 目標コースに対して平行に $0.05 \mathrm{~m}$ 幅のテープを貼っている. 以上より, 測定データと操縦者による操縦性評価を用いて, 各々の条件における操縦性を評価する。また, 図 7 に示すよう 周囲への危険防止用の柵を設け，衝突時の衝撃を緩和するためのクッションを配置した．なお，実験に際し，想 定される危険性はすべて事前に説明し，実験参加者の意思を確認し，同意書による承諾を得，倫理原則に基づき 実験を実施した ${ }^{(12)}$.

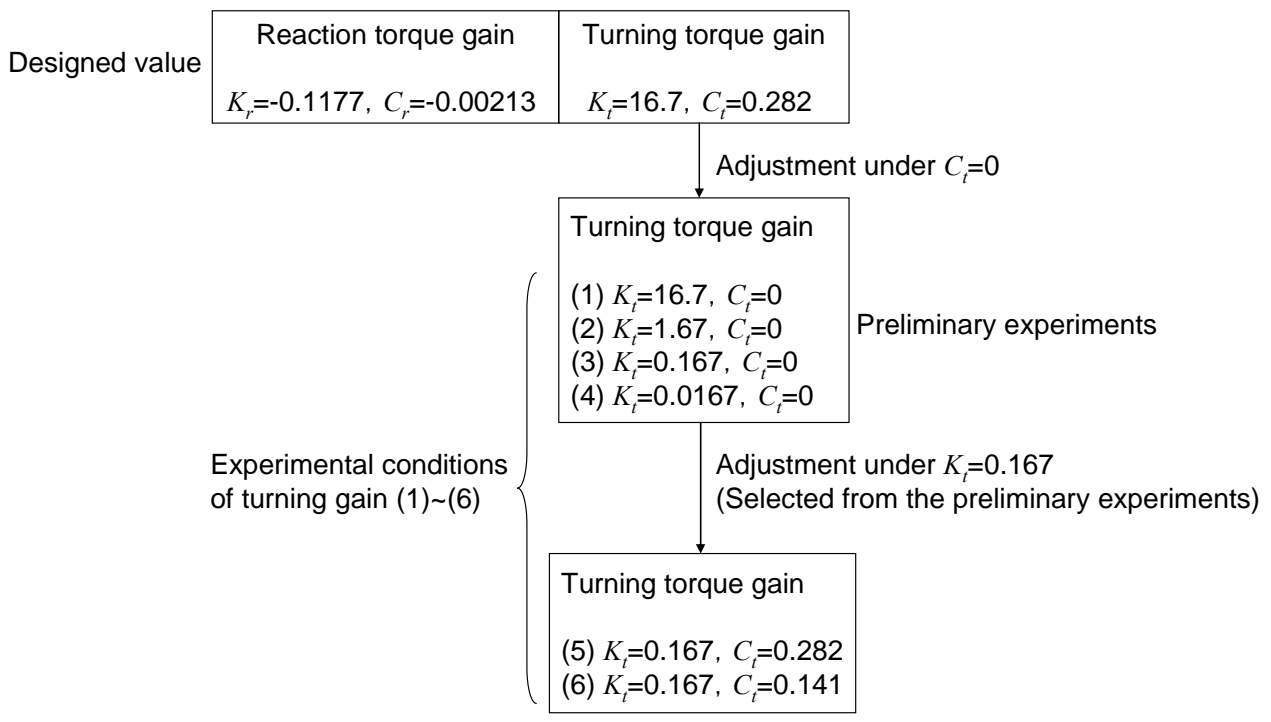

Fig.5 Flow diagram for setting the experimental conditions 
Table 1 Steering conditions for the turning experiments

\begin{tabular}{c|c|c|c|c|c|c}
\hline Condition & $(1)$ & $(2)$ & $(3)$ & $(4)$ & $(5)$ & $(6)$ \\
\hline$K_{t}$ & 16.7 & 1.67 & 0.167 & 0.0167 & 0.167 & 0.167 \\
\hline$C_{t}$ & 0 & 0 & 0 & 0 & 0.282 & 0.141 \\
\hline
\end{tabular}

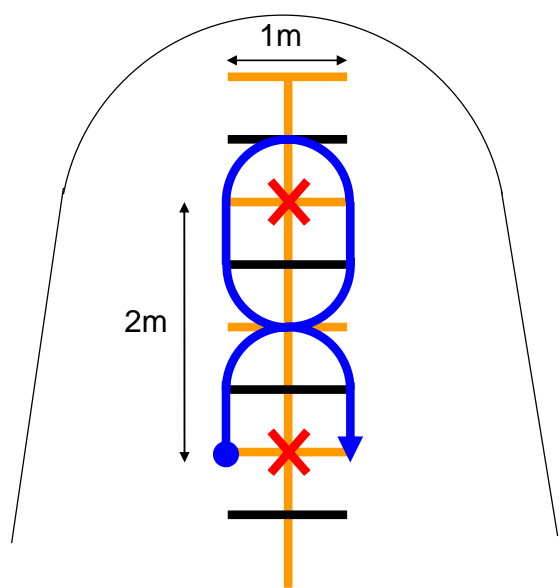

Fig.6 Test course of the turning experiment

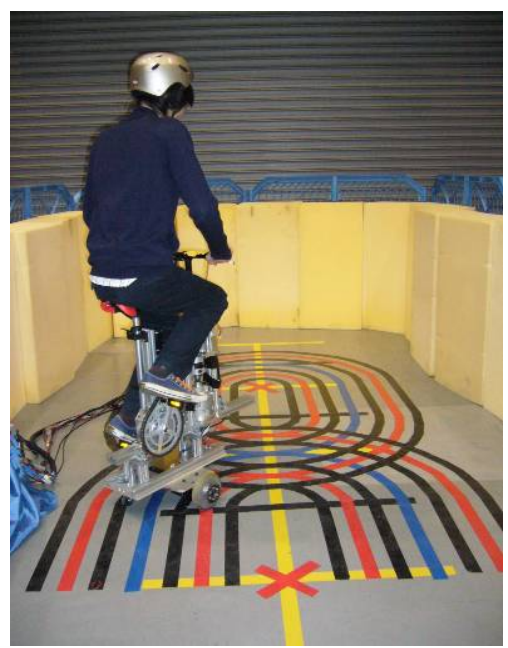

Fig.7 Maneuvering

\section{$3 \cdot 2$ 操舵反カアクチュエータの特性}

走行実験の前に, 操舵反カアクチュエータ単体の特性を示寸。ここでは, 操舵角に比例したトルク指令值に対 して，操舵反カトルクが一致することを確認した．操舵角に対する操舵反力トルク特性の評価試験結果を図 8 に 示す. 図 8 は, トルク指令ゲインが 0.05 , すなわち 20 度で $1 \mathrm{Nm}$ のトルクが発生する場合の結果である. 横軸に 操舵角, 縦軸に操舵反力トルクを示寸. これらより, 操舵角に比例したトルク指令值に対して, 操舵反力トルク が一致することが分かる，以上より，操舵反力アクチュエータシステムにおいて，目標通りの特性が得られてい ることを確認した. 


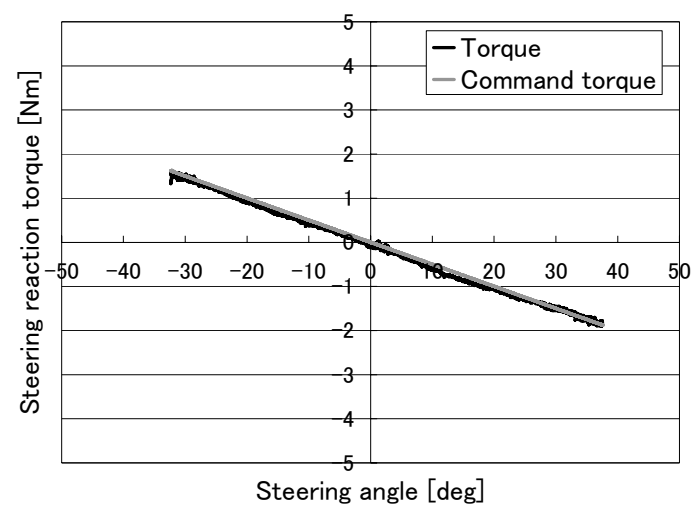

Fig.8 Characteristics of steering angle and steering torque (Torque command gain 0.05 (2.5 [Nm]/50 [deg]))

\section{4. 操舵制御実験結果}

表 1 に示寸操舵条件 1 6 6おける実験結果について述べ. 操舵条件 2〜6については，全員，転倒すること なく，到着点まで操縦することに成功した．操舵条件 1 においては，5名中 3 名が， 2 回の走行のうち，2回とも コースアウトし，到着点まで到達することができなかった，残り 2 名は，2 回とも到着点まで転倒することなく 到達できた. 図 9〜13に, 実験結果の一例として, 操舵条件 5 における車両の時刻歴データを示寸. 本結果は, すべての操舵条件において, 到着点まで転倒することなく到達した被験者のデータである. 図 9 は, 車輪の位置, 速度を示す. 前進が正であり, 車輪の回転移動距離として表している. 図 10 は, ペダルの回転角, 回転角速度を 示す. 従来の自転車のペダル回転における前進方向への回転が正で表される. 図 11 は, 車両のピッチ角, ピッチ 角速度を示寸. 車体前方一傾く場合が正と表される. 図 12 は, 操舵角, 操舵角速度, 図 13 は, 操舵反力を示寸. いずれも，時計回りが正である。図 9 より，車輪が前方に回転し，左右輪の回転差で走行を成していることが分 かる. 図 10 より, ピッチ角は $0 \sim 2$ 度の範囲で変動しながら, 走行していることが分かる. 図 11 より,ペダル は前方へ 0 120 deg/s の回転速度で, 回転し続けていることが分かる. 図 12 より, 操舵角は 10 度の範囲で変動 していることが分かる. また, 図 13 より, 操舵反力は, 操舵角と逆向きに発生していることが確認できる. これ らの結果は, 操舵制御実験結果の一例であるが, 他の条件また被験者についても, 走行に成功した場合は, ペダ ルを前方に回転させ，ハンドルを操舵させ，左右輪の回転差で操縦する基本的な運動は同様に確認できた.

次に, 操舵条件 1 6 における操舵角について, 比較する. 操舵条件 1,2 の場合, 操舵角を細かく変化させな がら操縦していることが分かった. 図 14 に, 操舵条件 2 における操舵角を示す. 操縦者にとって, 操舵角に乗ず る旋回ゲインが大きく，ハンドルを細かく回転させながら進行方向を調整したと考えられる．図 15 に操舵条件 3 における操舵角を示寸. 操舵条件 3 の場合, 操舵条件 1,2 に比へ，操舵角の変化は少ない. 図 16 に操舵条件 4 に おける操舵角を示寸．操舵条件 4 の場合, 操舵角は, \pm 40 度付近のストッパ限界まで達している. 旋回午インが 小さく, 操舵角を最大まで上げて旋回しきったことが分かる. 図 17 に操舵条件 6 における操舵角を示す. 操舵条 件 5,6の結果から，操舵角速度に乗ずる旋回ゲインが小さいほど，操舵角は大きくなることが分かる.

図 18 に目標コースに対寸る横方向の誤差を示す. 棒グラフの值は, 被験者の誤差の平均値, エラーバーは標準 偏差である. 誤差 $y_{\text {error }}$ は, 次式を用いて計算した。

$$
y_{\text {error }}=\frac{1}{T} \int_{0}^{T} \sqrt{\left(y(t)-y_{\text {des }}(t)\right)^{2}} d t
$$

ここで， $y$ は横方向位置， $y_{\text {des }}$ は目標横方向位置， $T$ は出発点から到達点に達するまでの時間である．操舵条件 4 における誤差が最も大きく, 操舵条件 5 における誤差が最も小さい. 図 19 に被験者の評価を示す. 思い通りに操 縦できたかを 5 段階で評価しており, 数值が高いほど思い通りに操縦できたことを示す. 縦軸の評価点は, 全被 験者の評価の平均值, エラーバーは標準偏差である. 操舵条件 1，4 の評価が低く, 操舵条件 5,6 の評価が高い. これらの結果は, 目標コースに対する横方向の誤差と同様の傾向にあることが分かる. 

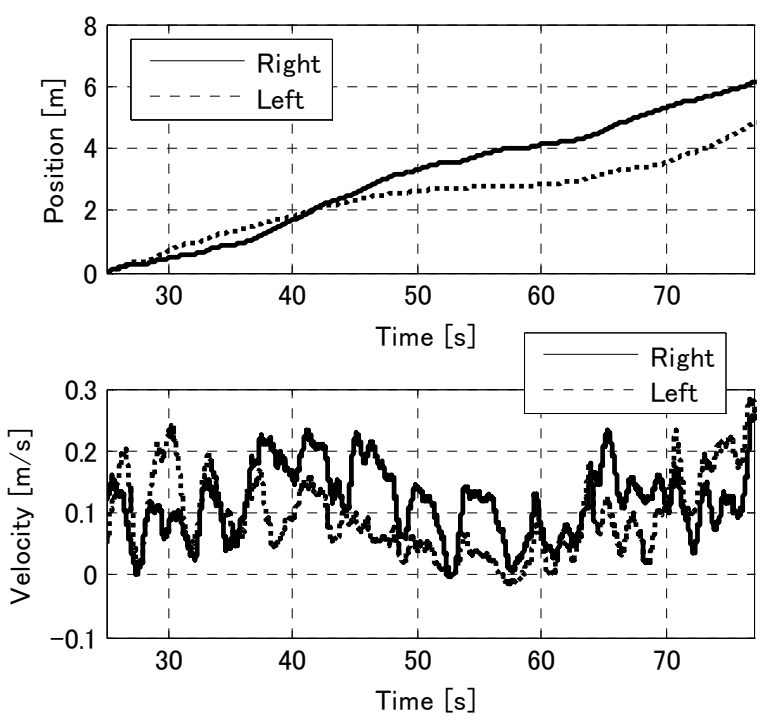

Fig.9 Position and velocity (condition 5)
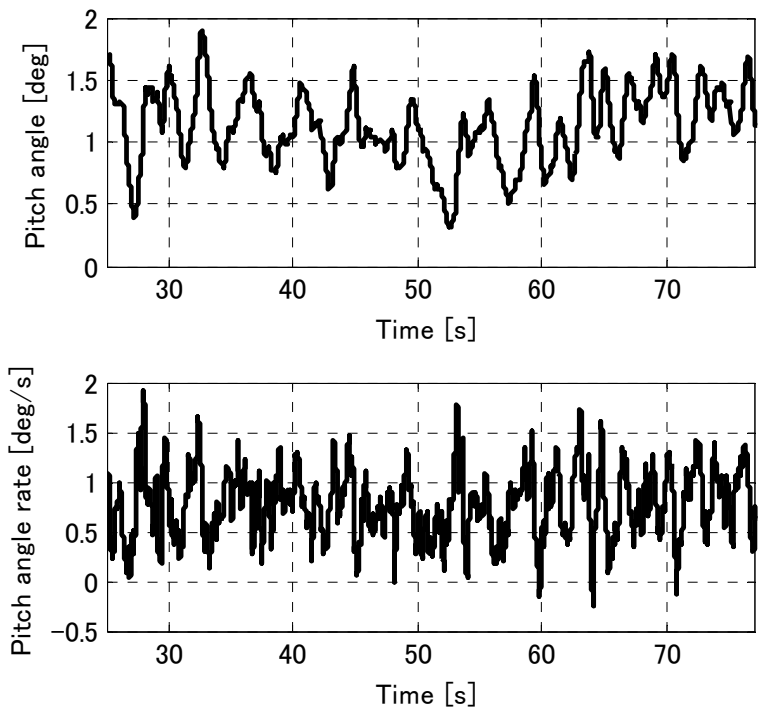

Fig.10 Pitch angle and pitch angle rate (condition 5)
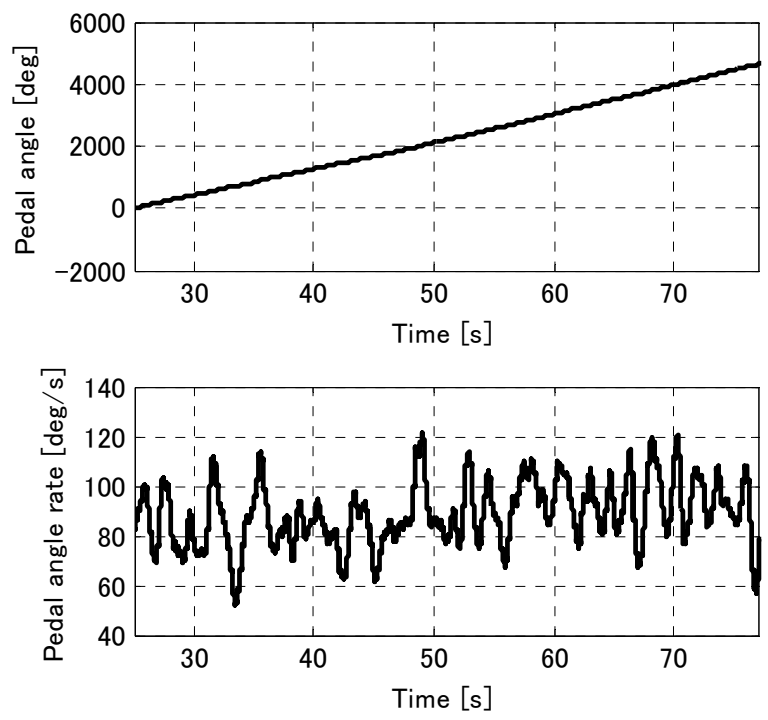

Fig.11 Pedal angle and pedal angle rate (condition 5) 

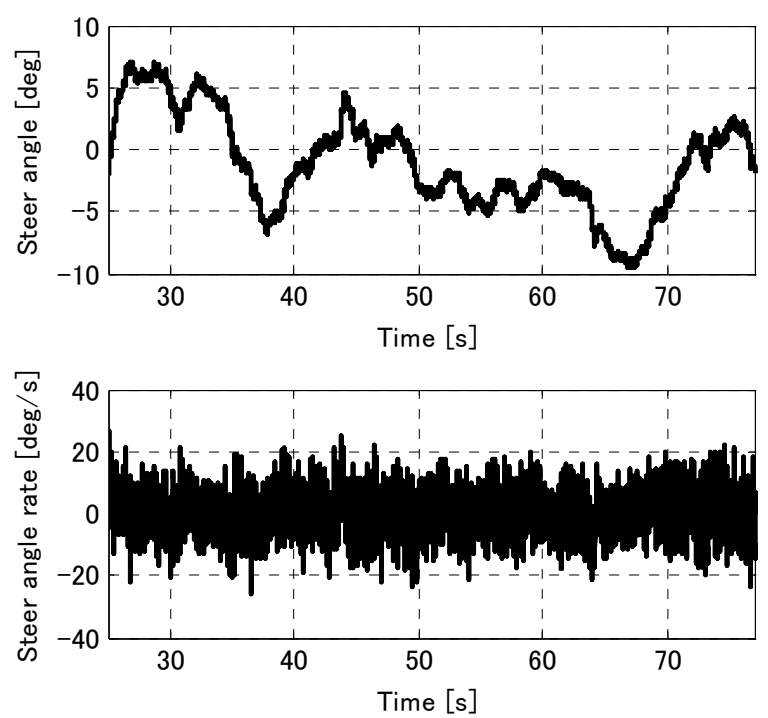

Fig.12 Steer angle and steer angle rate (condition 5)

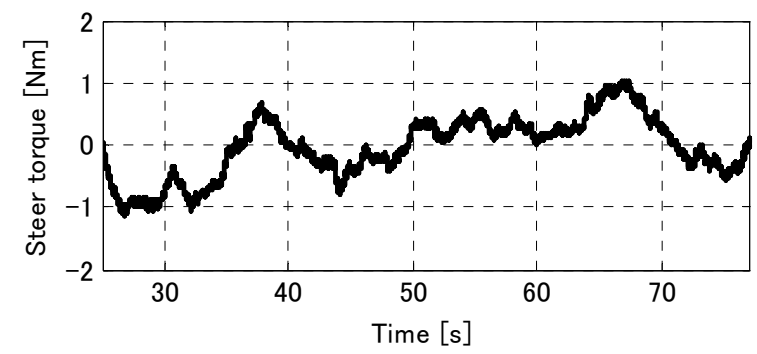

Fig.13 Steer torque (condition 5)

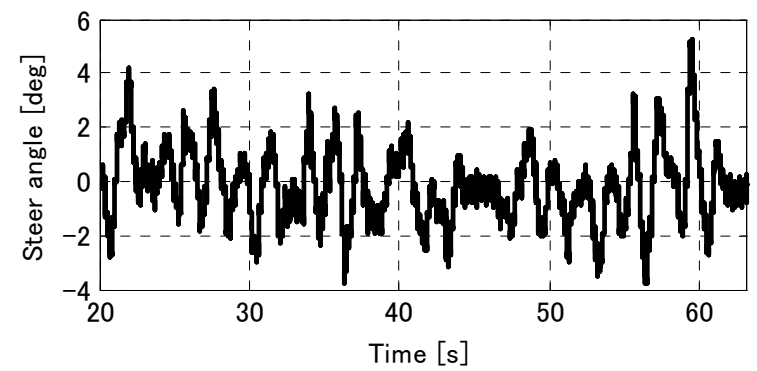

Fig.14 Steer angle (condition 2)

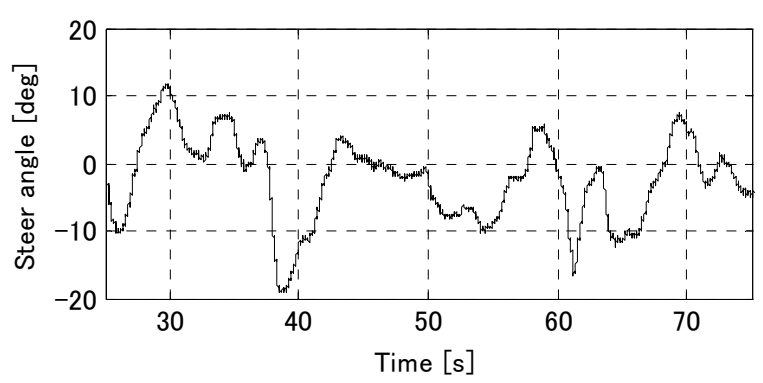

Fig.15 Steer angle (condition 3) 


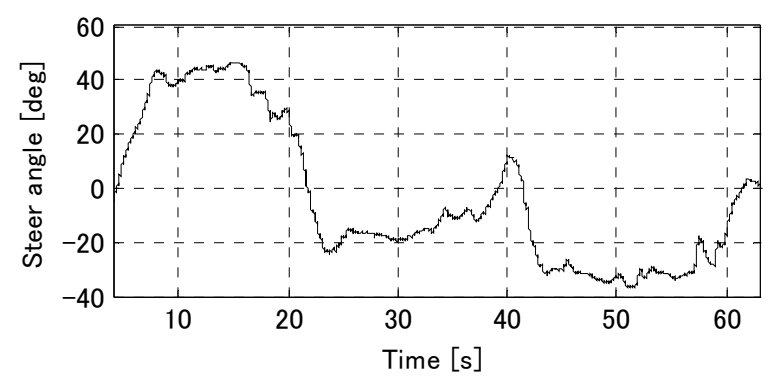

Fig.16 Steer angle (condition 4)

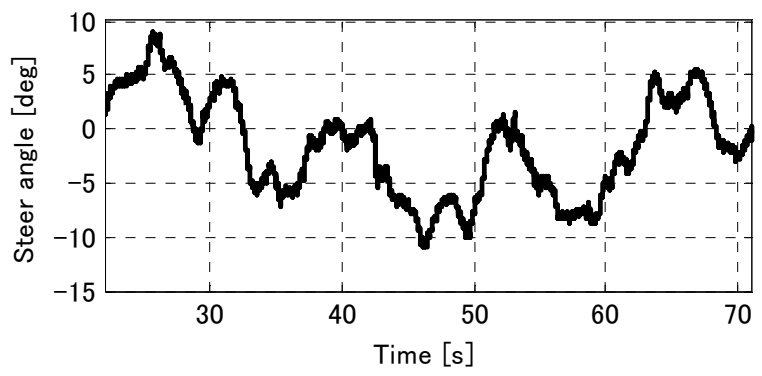

Fig.17 Steer angle (condition 6)

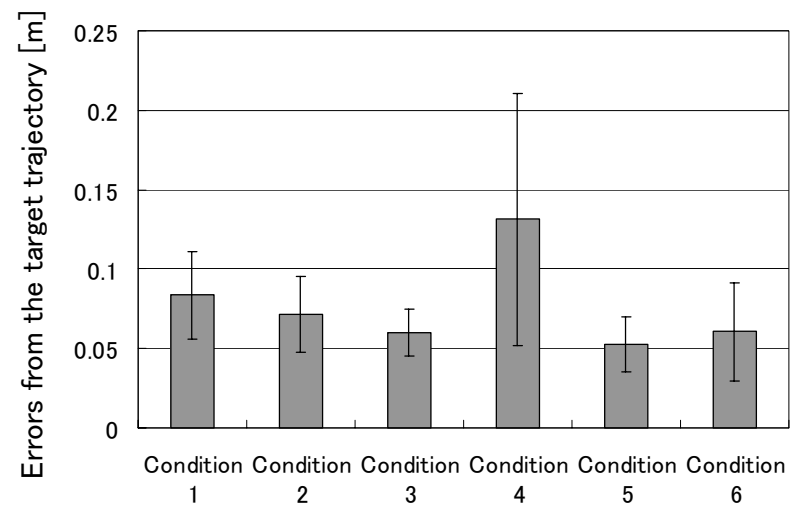

Fig.18 Errors from the target trajectory

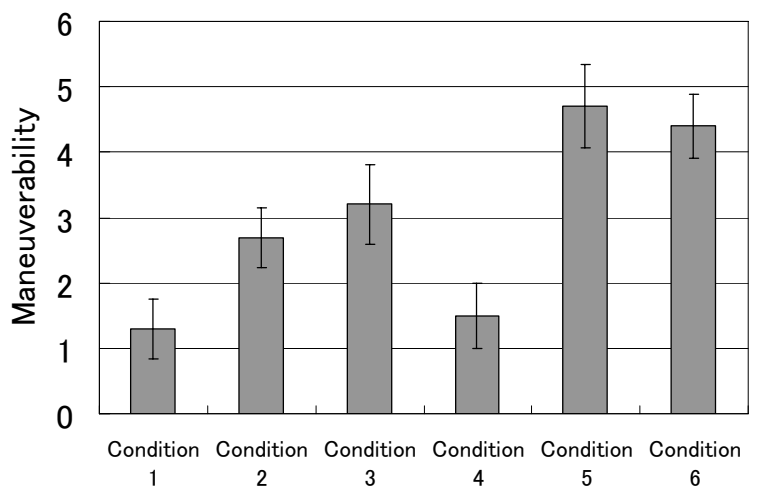

Fig.19 Maneuverability

以上より,ペダル式倒立振子型安定化車両では, 姿勢安定化制御と人間のペダル回転による進行を行いながら， ハンドルの回転によって旋回が可能であることが分かった．自転車モードとの互換性を考慮したハンドル反力系 を導入し，ハンドル操舵角と操舵角速度に適切な旋回ゲインを乗じて左右車輪駆動トルクを導出することで，高 い操縦性を持たせることが示された。 


\section{5. 結 論}

本研究では，人力駆動を利用したペダル式倒立振子型安定化車両の操舵性能について評価した. 得られた知見 を次にまとめる.

- 左右車輪の回転差によって旋回し, 操舵反力アクチュエータを備えたペダル式倒立振子型安定化車両を製作 した. 自転車の操舵に関する力学を利用した操舵システムを構築した.

- 小回り旋回を含む試験路において, 人がペダル式倒立振子型安定化車両に乗車し, 転倒することなく, 意図 する方向に旋回できることを確認した.

・実験結果より, 目標コースに対する横方向誤差と被験者の操縦性 5 段階評価は, 同じ傾向を示した.

・ ハンドル操舵角と操舵角速度に適切な旋回ゲインを乗じて左右車輪駆動トルクを導出する手法が, 高い操縦 性を有することが分かった.

今後, 走行速度を変化させたときの操舵反力ゲインの調整やロールの影響を考慮したシステム設計が課題と言 える.また，本研究成果を発展させ，人力駆動を利用した PMV の安定性と操縦性を，詳細な人間モデルを用い て検討していきたい.

\section{文献}

(1) Nakagawa, C., Suda, Y., Nakano, K. and Hirayama, Y., Maneuvering Experiment of Parallel Two-Wheeled Personal Mobility Vehicle with Human Pedaling, SEISAN-KENKYU, Vol. 62, No. 1, (2010), pp. 119-122.

(2) Pathak, K. Franch, J. and Agrawal, S.K., Velocity and Position Control of a Wheeled Inverted Pendulum by Partial Feedback Linearization, IEEE Transactions on Robotics, Vol.21, No.3, (2005), pp.505-513.

(3) Pathak, K.and Agrawal, S.K., Band-Limited Trajectory Planning and Tracking for Certain Dynamically Stabilized Mobile Systems, Transaction of the ASME, Journal of Dynamic Systems, Measurement and Control, Vol.128, No.3, (2006), pp.104-111.

(4) Sasaki, M., Yanagihara, N., Matsumoto, O. and Komoriya, K., Weight Personal Vehicle Operated by the Movement of Rider's Center-of-Gravity, Journal of Robotics Society of Japan, Vol.24, No.4, (2006), pp. 533-542.

(5) Kato, Y., Hosokawa, M. and Morita, M., Future, Personal Mobility i-unit, Journal of Society of Automotive Engineers of Japan, Vol. 60, No.2, (2006), pp. 97-102.

(6) Choi, D. and Oh, U., Human-friendly Motion Control of a Wheeled Inverted Pendulum by Reduced-order Disturbance Observer, IEEE International Conference on Robotics and Automation, (2008), pp. 2521-2526.

(7) The Industrial Property Digital Library, COAXIAL TWO-WHEEL VEHICLE, Publication number 2009-023652.

(8) Nakagawa, C., Nakano, K. and Suda, Y., Control of the Dynamically Stabilized Vehicle moved by Human Pedaling, Dynamics and Design Conference 2009 CD-R, (2009), No. 641

(9) Nakagawa, C., Nakano, K., Suda, Y. and Nabeshima, K., Proposal for Personal Mobility Vehicle, SEISAN-KENKYU, Vol. 61, No. 1, (2009), pp. 71-74

(10) Komoda, M., Control Engineering (in Japanese), Asakura shoten, (1993)

(11) Nakagawa, C., Dynamics and Control of Human-Friendly Personal Mobility Vehicles, Doctoral thesis, University of Tokyo, (2009)

(12) Ohsuga, M., Ethical issues related to the experiments using human subjects, Proceedings of 2009 JSAE Annual Congress (Spring), No.02-09, (2009), pp.1-4. 